\title{
A Literature Review of the Treatment of Black Triangles
}

\author{
Joanne Cunliffe ${ }^{*}$ and Ali Rizvi2* \\ 1Senior Lecturer, University Dental Hospital of Manchester, Higher Cambridge Street, United Kingdom \\ ${ }^{2}$ Dental Core Trainee, University Dental Hospital of Manchester, Higher Cambridge Street, United Kingdom
}

\section{${ }^{*}$ Corresponding authors:}

Joanne Cunliffe, Senior Lecturer, University Dental Hospital of Manchester, Higher Cambridge Street, United Kingdom; Tel: +440161275 6717; Fax: +440161275 6710 E-mail: joanne.cunliffe@manchester.ac.uk

Ali Rizvi BDS MFDS, Dental Core Trainee, University Dental Hospital of Manchester, Higher Cambridge Street, Manchester, M15 6FH, United Kingdom; Tel: +16174324247; Fax: +16174323881; E-mail: Ali.Rizvi@mft.nhs.uk

Received: March 06, 2019; Accepted: March 20, 2019; Published: April 25, 2019;

\begin{abstract}
Black triangles are a result of periodontal disease and can also be a response to treatment and return of health. They can also be a result of orthodontic treatment and tooth and root shape and position. They are perceived as unaesthetic and there is an increase in the demand for treatment. This paper will look at some of the treatment options that are available to treat black triangles. The treatment is often multidisciplinary and can involve orthodontics, surgery and restorative. As aim of this thesis is to aid the prediction of black triangles, as a solution to them needs to be sought. This paper explores the treatment of black triangles to help the clinician give the patients the options if it is predicted a black triangle may be present.
\end{abstract}

Method: An OVID MEDLINE search was undertaken using the term Black triangle AND treatment. This yielded 32 papers and of these 14 were related to dental black triangles. These 14 papers were the hand searched for their cited references and this yielded an additional 17 papers.

Conclusion: The treatment for black triangles can be difficult and in the case of surgical management very unpredictable. More research into simple predictable management needs to take place.

Key words: Black Triangles, Embrasure Space, Gingival Veneers, Periodontal Surgery

\section{Introduction}

Black triangles are both unaesthetic and can be an area where food can get trapped, which can lead to a worsening of gingival health and speech problems $[1,2]$. The balance between the gingiva and the teeth should be as natural as possible to improve the aesthetics [3, 4]. Before any treatment, such as periodontal and orthodontics, the possibility of black triangles should be discussed [5]. If the black triangle is to be treated then it is important to know the aetiology of it. A black triangle is present if the interdental papilla is not filling the space cervical to the interdental contact point.

Black triangles are associated with periodontal disease both treated and untreated, orthodontics and orthognathic surgery. They therefore become more common as patients get older and are more prevalent in adults $[5,6]$. It has been shown that patients older than 20 are more likely to have a black triangle than patients who are younger than 20 years old [7]. Patients who suffer from osteoporosis are also at an increased risk of developing gingival recession [8]. The tooth and the root morphology play a role in the presence of a black triangle. If the crown of the tooth is of a triangular shape then the patient is more likely to have a black triangle as the embrasure space will be larger. The embrasure space also plays a role in the aetiology of the black triangle [7]. The major aetiological factor for the presence of a black triangle is the contact point to the crest of bone distance. In periodontal disease there is loss of the interdental bone and this will therefore increase this distance between the contact point and the crest of the bone. Tarnow described the presence of a black triangle to be related to this distance and suggested that should a distance of $5 \mathrm{~mm}$ or less exist between the contact point and the crestal bone then a black triangle can be avoided. If the distance is greater than $6 \mathrm{~mm}$ then a $44 \%$ chance of a black triangle exists and if this is $7 \mathrm{~mm}$ or greater then in $73 \%$ of cases a triangle will be formed [9].

The more posterior area in the mouth, the larger the embrasure space is, and the smallest space is that between the central incisors $[10,11]$. The contact point is in fact a contact area and in the central incisor it is approximately $2 \mathrm{~mm} \times 2 \mathrm{~mm}$ [11]. There is a classification of loss of papilla height developed by Nordland and Tarnow [12]. They used three landmarks to classify the papilla loss: the contact point interdentally, the labial apical position of the Cemento-Enamel Junction (CEJ), and the interproximal coronal position of the cemento-enamel junction.

The classes were divided in to four groups (Figure 9.1).

- Normal - The papilla fills the space to the contact point.

- Class I - The papilla lies between the contact point and the most coronal position of the CEJ interproximally (the interproximal CEJ not visible).

- Class II - The papilla tip lies at or below the interproximal CEJ but coronal to the labial CEJ.

- Class III - The papilla tip lies at or above the labial CEJ. 
Black triangles are perceived as unattractive by both patients and professionals. The evidence that patients do not like black triangles comes from a study by Cunliffe and Pretty where patients were asked to rank black triangles against other dental problems and they found that patients ranked black triangles after caries and missing teeth [13]. Kokich demonstrated orthodontists identified a black triangle of $2 \mathrm{~mm}$ was unattractive whereas, general dental practitioners as well as the general public were unable to detect an open embrasure unless it was $3 \mathrm{~mm}$ in length [14]. Patients are more aware of dental aesthetics with the increase in media coverage and the rise of celebrity culture [15]. In the UK's 2009 Dental Health Survey 16\% of dentate adults had difficulty in smiling or showing their teeth [16].

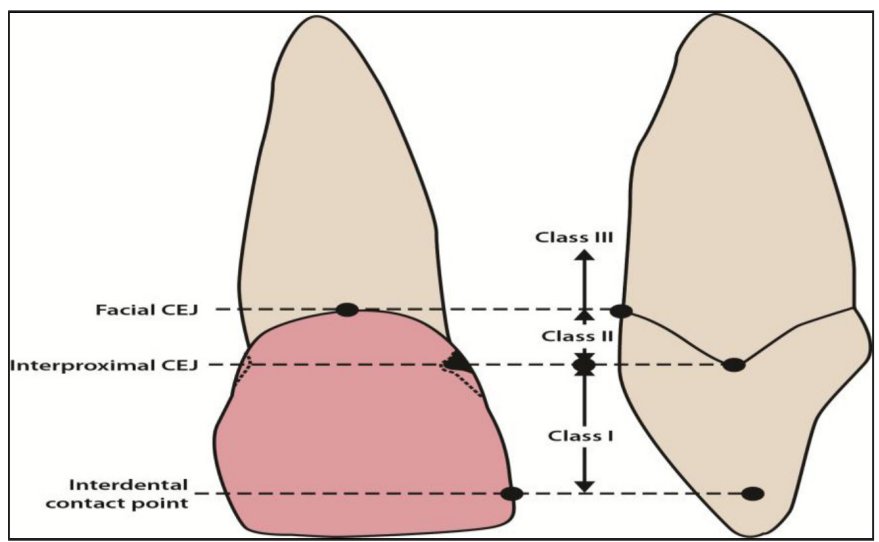

Figure 9.1. Classification of papilla loss.

\section{Treatment for black triangles}

The aetiology of black triangles is multifactorial; therefore it is best that each patient is assessed thoroughly in order to formulate the treatment which will best suit them [17]. The treatment may be a single modality but more often it is a multidisciplinary with orthodontic, surgical and restorative management.

\section{Orthodontic management}

Teeth of triangular morphology are liable to black triangle disease and can be treated with Inter-Proximal Reduction (IRP) and space closure. The IRP and space closure changes the contact to a more broad area therefore reducing the contact point distance resulting in a reduced embrasure space. IRP is performed with diamond strips or fine burs to remove the interproximal enamel and change the mesial contour of the teeth. Usually, only $0.5 \mathrm{~mm}-0.75 \mathrm{~mm}$ of enamel is removed to achieve the desired result [18]. Another factor to considerer is the root divergence as this increases the likelihood of black triangles. The normal angle between the roots of patients with normal inter-dental papilla was $3.65^{\circ}$ and if this increases by $1^{\circ}$ then there is an increase in the probability of a black triangle from $14 \%$ $21 \%$ [1]. Orthodontists must take care with the placement of brackets to reduce the risk of divergent roots. Therefore in adults with attrition, the brackets need to be placed perpendicular to the long axis of the tooth and not parallel to the incisal edge. In addition it is also useful to know the angulation of the roots before treatment and a periapical radiograph is advised [19]. As the roots become more parallel the contact point becomes more apical and lengthens. The result is the crowns become closer and the trans-septal fibres fill the space and relax, therefore reducing or eliminating the open space [18].

The amount of crowding that the anterior teeth have has little influence on black triangles after orthodontic treatment. In patients with less than $4 \mathrm{~mm}$ crowding and $4 \mathrm{~mm}$ to $8 \mathrm{~mm}$ crowding there was similar number of patients who had black triangles post treatment [5]. When the crowding was over $8 \mathrm{~mm}$, the percentage of black triangles went up by $7 \%$. As patients get older there is a decrease in the width/ length ratio as the crown of the tooth wears and becomes shorter. This changes the position and proportion of the contact point [20]. When a patient with previously treated periodontal disease is treated with orthodontics, care must be taken to explain that there may be marked interproximal recession that may need restorative management post orthodontics [21]. The other orthodontic management procedure is to take advantage of the fact that as a tooth is extruded the gingiva comes with it, and this may restore the interdental papilla with assistance of surgery [22].

\section{Periodontal condition}

It is important to make sure that the periodontal tissues are healthy and stable. If they are not there will be continued bone loss, which means that the tissues will further recede. The loss of the bone leads to an increase in the distance between the contact point to the crest of bone and an increased risk of a black triangle. It has been shown in several studies that when the distance between the contact point to the crest of the bone increases over $5 \mathrm{~mm}$, the percentage chance of having a black triangle increases $[9,19,23]$. Other periodontal considerations such as gingival inflammation, interproximal cleaning and gingival biotype need to be taken into account when assessing the risk of black triangles [13].

Tooth brushing trauma can also lead to black triangles and this includes overzealous use of interdental products. If this is suspected then interproximal cleaning should be stopped to see if the papilla recovers [24]. Patients who have thin gingival biotypes have a restricted blood supply at the papilla which results in altered healing [6]. Thin tissue is susceptible to trauma therefore it is best to educate the patient on atraumatic interdental cleaning [25].

\section{Surgical procedures}

The tissue interproximally is very fragile and the blood supply to this area is poor. Surgery works best on patients with thick tissue type, but it is patients with thin tissue who are more susceptible to recession. The thick tissue type has a better blood supply and rebound than the thin, whereas the thin tissue type tends to have permanent recession. This is why it is less predictable to use surgical procedures to correct interdental black triangles. There is also limited space to perform the procedures and it is difficult to place grafts due to limited access. If the papilla is damaged surgically then there is a risk the situation could be made worse. There was a study in 1965 when two papilla of 16 dental students were surgically removed and $69 \%$ failed to return to their original dimensions [26]. There have been micro surgical procedures undertaken to generate interdental soft tissue. They are very technique sensitive and their success will depend very much on 
the clinician's skill and experience. There have been some promising case studies that have shown some success $[27,28]$. Recently there has been a pilot study on the use of micronised acellular dermal matrix allograft technique which found it promising as there was significant increase in the papilla index [29]. This study was undertaken on 12 patients with 38 papilla defects and involved the use of powdered dermal matrix mixed with saline. It was then injected into a pouch that was formed by releasing the gingival papillary complex to move it coronally.

In implant treatment it is harder to produce a papilla as there is no interdental crest between two implants. It has a flat plate of bone that does not support the papilla as well. Tarnow looked at the presence of the papilla from the crest of the bone to contact point distance and found that only an average of $3.4 \mathrm{~mm}$ of gingival height could be achieved between two adjacent implants [30]. This group suggested that if two teeth need to be replaced in the aesthetic zone then it is better to place one and cantilever the other tooth from the implant. The edentulous area can be surgically enhanced with a connective tissue graft and an ovate pontic to develop an appearance of a papilla. When the area is enhanced with more soft tissue in the form of connective tissue grafts the amount of soft tissue above the bone can increase up to $9 \mathrm{~mm}$ [31]. The ovate pontic was developed in the 1980s [32] and it has a convex surface. This design allowed the illusion of an emergence profile. There is a larger area of contact between the pontic and the soft tissue and there is a degree of light pressure [33]. To use an ovate pontic there needs to enough width of the ridge. In the case of a thin narrow ridge, if an ovate pontic is to be used, then there will need to be surgical ridge augmentation.

The classification for ridge defects was developed by Seibert [34]

1. Class I - Loss of width of the ridge but the height remains the same.

2. Class II - Loss of the height but the width remains the same.

3. Class III - Loss of the width and the height.

The techniques to augment the ridge are:

- Socket preservation. Bone graft material is placed in the fresh extraction socket to reduce the collapse of the socket [35].

- A full thickness soft tissue graft. Free gingival graft is used as an onlay to correct the defect [34].

- Pouch flap. Involves the use of connective tissue being placed in a pouch to increase the width of the ridge. It was described by Garber and Rosenberg where the connective tissue was taken from the tuberosity [33]. This was a development from a previously described technique [36].

- Hydroxyapatite implant where hydroxtapatite particles or a block is placed sub gingival $[37,38]$.

- Connective tissue graft and partial thickness flap -- These grafts are placed under the mucosa to increase the thickness of the tissue [39].

- Provisional restoration. The temporary restoration is fitted after the extraction of a tooth and goes into the socket slightly to prevent the collapse of the socket [40].
The modified ovate pontic moves the apex from the centre to a more labial aspect (Figure 9.2)

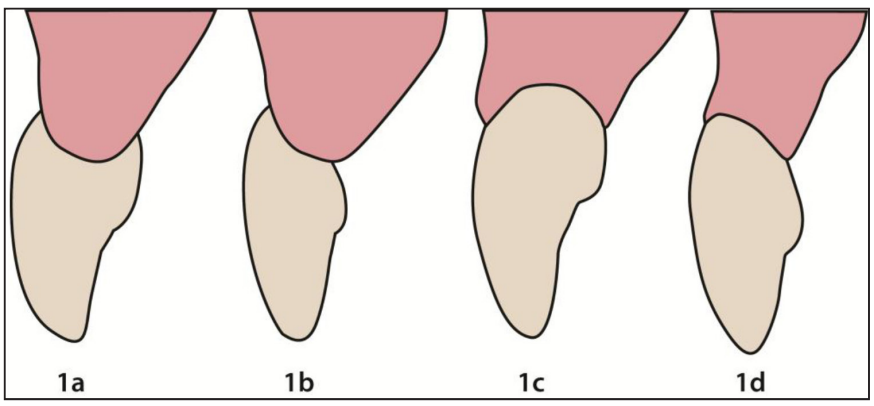

Figure 9.2. Pontic designs.

1a. Ridgelap, 1b. Modified ridgelap, 1c. Ovate pontic, 1d. Modified ovate pontic.

The modified ovate pontic is easier to clean and needs less width which therefore reduces the need to augment the edentulous ridge. The height of the apex is $1 \mathrm{~mm}-1.5 \mathrm{~mm}$ apical to the tissue height and from the labial surface. There have been reports of inflammation and swelling with the use of these ovate pontics [41-43]. If oral hygiene is maintained, however, it was found that in the premolar and molar regions ovate pontics were not associated with clinically obvious inflammation. When the tissue was looked at histologically the keratin layer was thinner and there was a change in the subepithelial connective tissue [44]. Other studies have also found that if oral hygiene is good, and the pontic is cleaned with floss or superfloss, the tissue will be clinically healthy $[45,46]$. When the ovate pontic exerted pressure on the tissue there is a thinning of the tissue but no histological changes [47].

Another suggestion to aid the papilla adjacent to implants is to place a temporary restoration on the implant after the second stage surgery which can be used to guide the tissues before the definitive restoration is made [48]. The subgingival tissue in the interproximal area of the temporary restoration will guide the tissue to the desired position [49]. The position of the implant in the bucco-lingual is also important to the aesthetics. If a line is drawn from the facial aspects of the adjacent teeth the centre of the implant should be at least $4 \mathrm{~mm}$ from this imaginary line [50]. This position reduces the risk of labial bone being lost which could lead to recession. The space that is needed mesio-distal is also important as there needs to be a minimum of $1.5 \mathrm{~mm}$ from the edge of the implant to the adjacent tooth. This will allow oral hygiene and the development of a papilla. So with a $4 \mathrm{~mm}$ implant there needs to be a $7 \mathrm{~mm}$ space to place it [48]. Some authors have developed flaps to create papilla at the exposure stage, one of which was a palatal flap rotated and split into two parts: one for the mesial and one for the distal [51]. There have also been techniques described to make it appear there is a papilla $[52,53]$.

\section{Restorative management}

Restorative management can be the sole treatment for the management of black triangles or it may be used in combination with orthodontics. There is the interproximal striping as described above to change the shape of a triangular tooth in order to change the length and position of the contact point. There has also been the use of indirect 
crowns and/or veneers [54] to increase the length of the contact point to mask the interproximal space. The problem with these treatments is that they need temporisation which can have a detrimental effect on the health of the gingiva. In addition, if the definitive restoration impinges on the gingiva, it may have a detrimental effect on the gingival health $[55,56]$. These have been also used with the pink porcelain where there is also labial recession but the problem with that is getting an exact colour match with the gingiva.

Over the years there have been improvements in bonding to enamel and dentine. There has also been much development in the aesthetics of composite resins and their wear and staining resistance. There has been an increase in the use of direct composite restoration to mask the embrasure space. This method is economically viable, quick and non-invasive. Bichacho suggested that there is no logical reason for macro mechanical preparation to close black spaces and achieve the desired contour [57]. It has also been shown to produce predictable results $[58,59]$. The composite is placed slightly into the gingival sulcus which helps guide the shape of the interdental papilla $[57,60]$. This technique using composite in the sulcus is described by Clark [61] who uses a matrix interproximally with an aggressive cervical contour and staged wedging.

For this technique to be successful the patient needs excellent oral hygiene otherwise the control over the gingiva will be lost, as the tissues will become inflamed due to the presence of plaque [47]. If the area that contacts the gingival is polished and smooth there will be no adverse effects if the patient has good oral hygiene [62]. These direct restorations to fill in the interdental space relies on the cervical contour [62] and the contact point position [9]. To allow the formation of the interdental papilla there needs to be $3 \mathrm{~mm}-5 \mathrm{~mm}$ of soft tissue present [63]. With this minimal thickness the tissue can compress and reshape.

\section{Hyaluronic acid}

The hyaluronic acid is derived from a streptococcus species of bacteria of a high degree of purity [64], and then cross linked up to $1 \%[65,66]$ This product has been used to correct facial creases and bulk tissue in the face [67]. The commercial product used in the UK is Restylane $^{\mathrm{TM} *}$ and this is registered with the Medicines and Healthcare Products Regulatory Agency (MHRA) for adverse effects reporting. An adverse effects form has been made to record any reactions to the product (Appendix 5).

The product was first evaluated in Sweden and Italy $[66,68]$. Both these studies showed good and sustained results at 6-8 months later. The adverse effects of the treatment were evaluated and it was found that in 1999 only one in every $650(0.15 \%)$ of patients treated with Restylane had redness, local granulomatous reaction, swelling, acneiform or bacterial infection [69]. Since then the product has been purified even more and by 2000 this dropped to $0.06 \%$ [69]. As the purification process has improved and hypersensitivity reactions are as low as $0.02 \%$, no skin testing is needed [70]. Hyaluronic acid is very hydrophilic, and can form a gel at low concentrations and has a large volume to mass [71]. This property makes it ideal to produce volume in the tissue. Becker et al carried out a self-funded study where 14 black spaces were treated with Hyaluronic acid (4 teeth and 10 implants). Each site was evaluated for the percentage change between the initial and final applications. 3 sites had 100\% improvements whereas 8 sites had 88 to $97 \%$ improvement. All the patients thought the treatment was painless and 6 thought there was significant improvement [72].

\section{Conclusion}

Black triangles come about as a result of tooth shape, root angulation, orthodontic treatment and most often bone loss due to periodontal disease. The treatment can be multidisciplinary but before it is undertaken the aetiology of the recession needs to be explored because it may have a bearing on the treatment that is being done. Therefore treatment planning to reduce the formation of black triangles during treatment and careful work up is needed. Before any restorative treatment is undertaken it is important to do a diagnostic wax up the see the width/height ratio of the teeth after the restorations. It is advisable to not exceed the width of an anterior tooth by more than $80 \%$ of its length [73]. There may also be an imbalance in the proportions such as the 'golden proportions' [74]. As the treatment of black triangle can be unpredictable more research is needed to find simple, less invasive and more predictable methods.

\section{References}

1. Kurth JR, Kokich VG (2001). Open gingival embrasures after orthodontic treatment in adults: prevalence and etiology. Am J Orthod Dentofacial Orthop 120:116-123. [crossref]

2. Takei HH (1980) The interdental space. Dent Clin North Am 24: 169-176. [crossref]

3. Moskowitz ME, Nayyar A (1995) Determinants of dental esthetics: a rational for smile analysis and treatment. Compend Contin Educ Dent 16: 1164. [crossref]

4. Singh VP, Uppoor AS, Nayak DG, Shah D (2013) Black triangle dilemma and its management in esthetic dentistry. Dental research journal 10: 296-301. [crossref]

5. Ko-Kimura N, Kimura-Hayashi M, Yamaguchi M, Ikeda T, Meguro D, et al. (2003) Some factors associated with open gingival embrasures following orthodontic treatment. Australian Orthodontic Journal 19: 19-24. [crossref]

6. Chow YC, Eber RM, TsaoY, Shotwell JL, Wang H (2010) Factors associated with the appearance of gingival papillae. Journal of Clinical Periodontology 37: 719727. [crossref]

7. Chang L (2007) The association between the embrasure morphology and and central papilla recession: a noninvasive method of assessment. Chang Gung Med J 30: 445-452. [crossref]

8. Shum I, Leung P, Kwok A, Corbet EF, Orwoll ES, et al. (2010) Periodontal Conditions in Elderly Men With and Without Osteoporosis or Osteopenia. Journal of Periodontology 81: 1396-1402. [crossref]

9. Tarnow DP, Magner AW, Fletcher P (1992) The effect of the distance from the contact point to the crest of bone on the presence or absence of the interproximal dental papilla. J Periodontol 63: 995-996. [crossref]

10. Blitz N (1997) Criteria for success in creating beautiful smiles. Oral Health 87: 38-42. [crossref]

11. Morley J, Eubank J (2001) Macroesthetic elements of smile design. J Am Dent Assoc 132: 39-45. [crossref]

12. Nordland WP, Tarnow DP (1998) A classification system for loss of papillary height. J Periodontol 69: 1124-1126. [crossref]

13. Cunliffe J, Pretty I (2009) Patients' ranking of interdental "black triangles" against other common aesthetic problems. European Journal of Prosthodontics \& Restorative Dentistry 17: 177-181. [crossref]

14. Kokich VO Jr, Kinzer GA (2005) Managing congenitally missing lateral incisors. Part I: Canine substitution. J Esthet Restor Dent 17: 5-10. [crossref]

15. Ahmad I (2010) Risk management in clinical practice. Part 5. Ethical considerations for dental enhancement procedures. British Dental Journal 209: 207-214.

16. Steele S, O' Sullivan I (2011) Adult Dental Health Survey 2009 N. statistics, The Health and Social Care Information Centre.

17. AlAhmari F (2018) Reconstruction of Lost Interdental Papilla: A Review of Nonsurgical Approaches. Journal of Dental and Medical Sciences 17: 59-65.

18. Kokich VG (1996) Esthetics: the orthodontic-periodontic restorative connection. Semin Orthod 2: 21-30. [crossref] 
19. Wu YJ, Tu YK, Huang S, Chan C (2003) The influence of the distance from the contact point to the crest of bone on the presence of the interproximal dental papilla. Chang Gung Med J 26: 822-828. [crossref]

20. Kokich VG, Spear FM (1997) Guidelines for managing the orthodontic-restorative patient. Semin Orthod 3: 3-20. [crossref]

21. Zachrisson B (2005) Orthodontics and periodontics. Clinicail periodontology and Implant dentistry - Jan Lindhe.

22. Carnio J (2004) Surgical reconstruction of interdental papilla using an interposed subepithelial connective tissue graft: a case report. Int $J$ Periodontics Restorative Dent 24: 31-37. [crossref]

23. Chang LC (2008) Assessment of parameters affecting the presence of the central papilla using a non-invasive radiographic method. J Periodontol 79: 603-609. [crossref]

24. Tanaka OM, Furquim BD, Pascotto RC, Ribeiro GL, Bósio JA, et al. (2008) The dilemma of the open gingival embrasure between maxillary central incisors. $J$ Contemp Dent Pract 9: 92-98. [crossref]

25. Kandasamy S, Goonewardene M, Tennant M (2007) Changes in interdental papillae heights following alignment of anterior teeth. Aust Orthod J 23: 16-23. [crossref]

26. Holmes CH (1965) Morphology of the interdental papillae. J Periodontol 36: 455 460. [crossref]

27. Nemcovsky CE (2001) Interproximal papilla augmentation procedure: a nove surgical approach and clinical evaluation of 10 consecutive procedures. Int $J$ Periodontics Restorative Dent 21: 553-559. [crossref]

28. Checchi L, Montevecchi M, Checchi V, Bonetti GA (2009) A modified papilla preservation technique, 22 years later. Quintessence Int 40: 303-311. [crossref]

29. Geurs NC, Romanos AH, Vassilopoulos PJ, Reddy MS (2012) Efficacy of micronized acellular dermal graft for use in interproximal papillae regeneration. International Journal of Periodontics \& Restorative Dentistry 32: 49-58. [crossref]

30. Tarnow D, Elian N, Fletcher P, Froum S, Magner A, et al. (2003) Vertical distance from the crest of bone to the height of the interproximal papilla between adjacent implants. Journal of Periodontology 74: 1785-1788. [crossref]

31. Elian N, Jalbout ZN, Cho SC, Froum S, Tarnow DP (2003) Realities and limitations in the management of the interdental papilla between implants: three case reports. Pract Proced Aesthet Dent 15: 737-744. [crossref]

32. Abrams L (1980) Augmentation of the deformed residual edentulous ridge for fixed prosthesis. Compend Contin Educ Gen Dent 1: 205-213. [crossref]

33. Garber DA, Rosenberg ES (1981) The edentulous ridge in fixed prosthodontics. Compend Contin Educ Dent 2: 212-223. [crossref]

34. Seibert JS (1983) Reconstruction of deformed, partially edentulous ridges, using full thickness onlay grafts. Part I. Technique and wound healing. Compend Contin Educ Dent 4: 437-453. [crossref]

35. Greenstein G, Jaffin RA, Hilsen KL, Berman CL (1985) Repair of anterior gingival deformity with durapatite. A case report. J Periodontol 56: 200-203. [crossref]

36. Langer B, Calagna L (1980) The subepithelial connective tissue graft. Journal of Prosthetic Dentistry 44: 363-367. [crossref]

37. Kaldahl WB, Tussing GJ, Wentz FM, Walker JA (1982) Achieving an esthetic appearance with a fixed prosthesis by submucosal grafts. J Am Dent Assoc 104: 449-452. [crossref]

38. Allen EP, Gainza CS, Farthing GG, Newbold DA (1985) Improved technique for localized ridge augmentation. A report of 21 cases. J Periodontol 56: 195-199. [crossref]

39. Langer B, Calagna LJ (1982) The subepithelial connective tissue graft. A new approach to the enhancement of anterior cosmetics. Int J Periodontics Restorative Dent 2: 22-33. [crossref]

40. Spear FM (1999) Maintenance of the interdental papilla following anterior tooth removal. Pract Periodontics Aesthet Dent 11: 21-28. [crossref]

41. Henry PJ, Johnston JF, Mitchell DF (1966) Tissue changes beneath fixed partial dentures. Journal of Prosthetic Dentistry 16: 937-947. [crossref]

42. Cavazos EJr (1968) Tissue response to fixed partial denture pontics. Journal of Prosthetic Dentistry 20: 143-153. [crossref]

43. Schield HW (1968) The influence of bridge pontics on oral health. J Mich State Dent Assoc 50: 143-147. [crossref]

44. Zitzmann NU, Marinello CP, Berglundh T (2002) The ovate pontic design: a histologic observation in humans. Journal of Prosthetic Dentistry 88: 375-380. [crossref]

45. Silness J, Gustavsen F, Mangersnes K (1982) The relationship between pontic hygiene and mucosal inflammation in fixed bridge recipients. $J$ Periodontal Res 17: 434 439. [crossref]

46. Tolboe H, Isidor F, Budtz-Jörgensen E, Kaaber S (1987) Influence of oral hygiene on the mucosal conditions beneath bridge pontics. Scand J Dent Res 95: 475-482. [crossref]

47. Tripodakis AP, Constandtinides A (1990) Tissue response under hyperpressure from Convex pontics. Int J Periodontics Restorative Dent 10: 408-414. [crossref]
48. Zuccati G (1993) Implant therapy in cases of agenesis. J Clin Orthod 27: 369-373. [crossref]

49. Senty EL (1976) The maxillary cuspid and missing lateral incisors: esthetics and occlusion. Angle Orthod 46: 365-371. [crossref]

50. Adell R, Eriksson B, Lekholm U, Brånemark PI, Jemt T (1990) Long-term followup study of osseointegrated implants in the treatment of totally edentulous jaws. Int J Oral Maxillofac Implants 5: 347-359. [crossref]

51. Nemcovsky CE, Artzi Z, Moses O (2000) Rotated palatal flap in immediate implant procedures. Clinical evaluation of 26 consecutive cases. Clin Oral Implants Res 11: 83-90. [crossref]

52. Becker W, Becker BE (1996) Flap designs for minimization of recession adjacent to maxillary anterior implant sites: a clinical study. Int J Oral Maxillofac Implants 11: 46-54. [crossref]

53. Palacci P, Nowzari H (2008) Soft tissue enhancement around dental implants. Periodontol 2000 47: 113-132. [crossref]

54. de Araujo, E. M., Jr., L. N. Baratieri, et al. (2003) Direct adhesive restoration of anterior teeth: Part 2. Clinical protocol. Pract Proced Aesthet Dent 15: 351-357. [crossref]

55. Sorensen SE, Larsen IB, Jörgensen KD (1986) Gingival and alveolar bone reaction to marginal fit of subgingival crown margins. Scand J Dent Res 94: 109-114. [crossref]

56. Sorensen JA (1989) A rationale for comparison of plaque-retaining properties of crown systems. J Prosthet Dent 62: 264-269. [crossref]

57. Bichacho N (1998) Papilla regeneration by noninvasive prosthodontic treatment segmental proximal restorations. Pract Periodontics Aesthet Dent 10: 75, 77-78. [crossref]

58. Portalier L (1996) Diagnostic use of composite in anterior aesthetics. Pract Periodontics Aesthet Dent 8: 643-652. [crossref]

59. De Araujo EM Jr, Fortkamp S, Baratieri LN (2009) Closure of Diastema and Gingival Recontouring Using Direct Adhesive Restorations: A Case Report. $J$ Esthet Restor Dent 21: 229-241. [crossref]

60. Bichacho N, Landsberg CJ (1997) Single implant restorations: prosthetically induced soft tissue topography. Pract Periodontics Aesthet Dent 9: 745-752. [crossref]

61. Clark D (2008) "Restoratively driven papilla regeneration: correcting the dreaded "black triangle". Tex Dent J 125: 1112-1115. [crossref]

62. Bichacho N (1996) Cervical contouring concepts: enhancing the dentogingival complex. Pract Periodontics Aesthet Dent 8: 241-254. [crossref]

63. Jacques LB, Coelho AB, Hollweg H, Conti PC (1999) Tissue sculpturing: an alternative method for improving esthetics of anterior fixed prosthodontics. Journal of Prosthetic Dentistry 81: 630-633. [crossref]

64. Baumann L (2004) Replacing dermal constituents lost through aging with dermal fillers. Seminars in cutaneous medicine and surgery 23: 160-166. [crossref]

65. Malson T, Lindqvist BL (1987) Gel of crosslinked hyaluronic acid for use as a vitreous humor substitute, Google Patents.

66. Duranti F, Salti G, Bovani B, Calandra M, Rosati ML (1998) Injectable hyaluronic acid gel for soft tissue augmentation. Dermatologic surgery 24: 1317-1325. [crossref]

67. Rohrich RJ, Ghavami A, Crosby MA (2007) The role of hyaluronic acid filler (Restylane) in facial cosmetic surgery: review and technical considerations. Plast Reconstr Surg 120: 41-54. [crossref]

68. Olenius M (1998) The first clinical study using a new biodegradable implant for the treatment of lips, wrinkles, and folds. Aesthetic plastic surgery 22: 97-101. [crossref]

69. Friedman PM, Mafong EA, Kauvar AN, Geronemus RG (2002) Safety data of injectable nonanimal stabilized hyaluronic acid gel for soft tissue augmentation. Dermatologic surgery 28: 491-494. [crossref]

70. Medicis Aesthetics, I. Restylane injectable gel (nonanimal stabalized hyaluronic acid; NASHA) package insert, Scottsdale Ariz.: Medicis Aesthetics.

71. Alberts B, Johnson A, Lewis J, Raff M, Roberts K, et al. (2002) The molecular Biology of the Cell. New York, Garland Science 45.

72. Becker W, Gabitov I, Stepanov M, Kois J, Smidt A, et al. (2010) Minimally invasive treatment for papillae deficiencies in the aesthetic zone: a pilot study. Clin Implant Dent Relat Res 12: 1-8. [crossref]

73. de Araujo EM Jr, B. L., Monteiro S. Jr, et al. (2003) Direct adhesive restoration of anterior teeth: part 3: procedural considerations. Pract Proced Aesthet Dent 15: 433-437. [crossref]

74. Magne P, Belser U (2003) Bonded porcelain restorations in the anterior dentition: a biomimetic approach. Chicago (IL), Quintessence Books.

\section{Citation:}

Joanne Cunliffe, Ali Rizvi (2019) A Literature Review of the Treatment of Black Triangles. J Dent Maxillofacial Res Volume 2(1): 1-5. 